\title{
Anemia megaloblastică la copil: Serii de cazuri dintr-o singură instituție şi revizuirea literaturii
}

\author{
Andreea Oltean ${ }^{1}$, Mihaela Ioana Chinceşan ${ }^{2}$, Maria Despina Baghiu', Eniko Molnar ${ }^{3}$, \\ Cristina Oana Mărginean² \\ ${ }^{1}$ Clinica Pediatrie I, Spitalul Clinic Judeţean de Urgenţă, Tg. Mureş, România \\ ${ }^{2}$ Clinica Pediatrie I, Universitatea de Medicină şi Farmacie, Tg. Mureş, România \\ ${ }^{3}$ Laborator de Analize Medicale, Spitalul Clinic Judeţean de Urgenţă, Tg. Mureş, România
}

\begin{abstract}
Acidul folic şi cobalamina sunt vitamine din grupul B, care joacă un rol esenţial în numeroase procese celulare. Deficienţa uneia sau a ambelor vitamine provoacă anemie megaloblastică, o anemie foarte rară la copii, caracterizată prin prezenţa megaloblaştilor. Deficienta de vitamina $B_{12}$ poate fi determinată de un aport redus, scăderea absorbţiei sau afectarea utilizării. Prezentăm cinci cazuri de anemie megaloblastică care ilustrează apariţia anemiei la vârste diferite şi în patologii diferite.

Concluzionăm astfel că anemia megaloblastică este o anemie rar diagnosticată la copii, cu multiple cauze, producându-se în contextul unei diete vegetariene sau asociată unei boli autoimune, dar şi prin malnutriţia protein-calorică a mamei în timpul sarcinii şi prezenţa anemiei megaloblastice la mamă, asociată cu lipsa de substituţie în timpul sarcinii şi în timpul alăptării.
\end{abstract}

Cuvinte cheie: anemie megaloblastică, megaloblaşti, vitamina $B_{12}$, acid folic

\begin{abstract}
Abrevieri
$\mathrm{Hgb}$ - Hemoglobină

MCHC - concentrația medie a hemoglobinei (mean corpuscular hemoglobin concentration)

$\mathrm{MCV}$ - volum mediu eritrocitar (mean corpuscular volume)
\end{abstract}

\section{INTRODUCERE}

Anemia megaloblastică este o anemie macrocitară, cauzată de carența de cobalamină, acid folic sau ambele (1). Vârsta medie de apariție este de 60 ani, fiind rară la copii, excepție făcând țările subdezvoltate, unde, din cauza condițiilor socio-economice precare şi a lipsei de vitamina $B_{12}$ în alimentaţie, este mai frecventă. De asemenea, este mai frecvent asociată cu bolile autoimune (2).

Vitamina $\mathrm{B}_{12}$ este o vitamină hidrosolubilă şi joacă un rol major în reacțiile metabolice. Oamenii sunt total dependenți de vitamina $\mathrm{B}_{12}$ din dietă. Sursele alimentare de vitamina $B_{12}$ sunt aproape exclusiv de natură animală (3). Deficitul de vitamina $\mathrm{B}_{12}$ poate să apară la sugarii alăptați de către mame strict vegetariene sau cu anemie megaloblastică; de asemenea, poate fi cauzat de malabsorbția intestinală din boala Crohn, celiachie, pancreatita cronică, infestații cu Diphyllobothrium latum sau după rezecția ileonului terminal $(1,4)$. Malabsorbția vitaminei $\mathrm{B}_{12}$ cauzată de deficitul de factor intrinsec este foarte rară la copil. Deficitul de acid folic este, de asemenea, determinat de carenţa nutriţională, malabsorbție sau nevoi crescute.

Anemia megaloblastică este o anemie care se caracterizează prin prezența celulelor precursoare, megaloblaşti în măduva osoasă şi macrocite în sângele periferic. Megaloblaştii apar din cauza sintezei deficitare de ADN, urmată de eritropoieza ineficientă. Celelalte modificări sunt reprezentate de o valoare scăzută a hemoglobinei şi a numărului de eritrocite, un volum mediu eritrocitar crescut (MCV $>100 \mathrm{fL}$ ), concentrația medie a hemoglobinei 
(MCHC) crescută, trombocitopenie, număr scăzut de reticulocite. Un nivel seric scăzut de vitamina $B_{12}$ ( $\mathrm{VN}=191-663 \mathrm{pg} / \mathrm{ml})$, respectiv de acid folic (VN=4.6-18.7 ng/ml) susține diagnosticul pozitiv (5).

În funcție de tipul de deficit, tratamentul constă în substituția vitaminei $\mathrm{B}_{12}$, inițial în doză de atac intramuscular, apoi lunar câte o doză de întreținere sau administrare de acid folic p.o până la corectarea anemiei şi a megaloblastozei (6).

Vom prezenta 5 cazuri de anemie megaloblastică, diagnosticate într-un Spital Terțiar de Pediatrie, Spitalul de Urgență Tg. Mureş, în perioada 2015-2018.

\section{SERIE DE CAZURI}

\section{Cazul 1}

Pacientă în vârstă de 15 ani, de sex feminin, cu dietă predominant vegetariană, s-a internat pentru

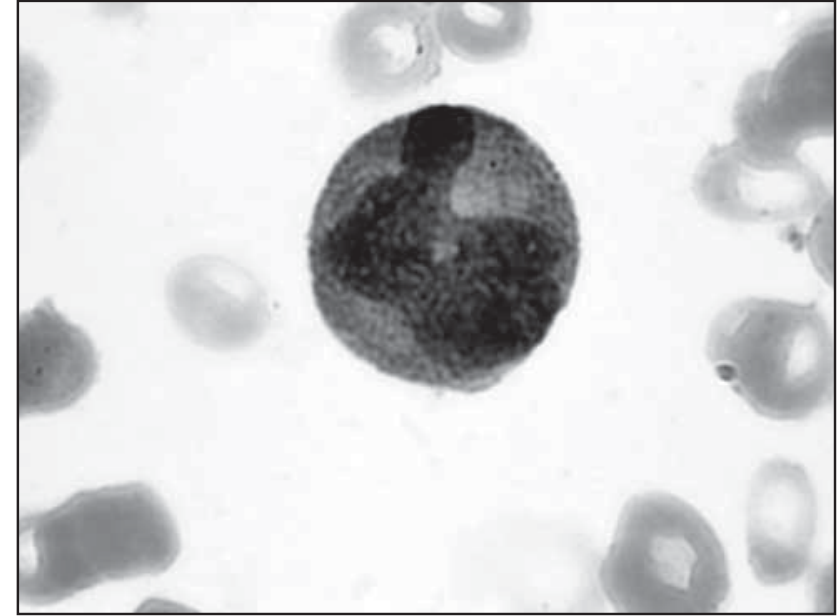

FIGURA 1. Aspirat de măduvă osoasă - se observă hipercelularitate cu metamielocite gigante

fatigabilitate, oboseală la eforturi mici/moderate, paloare, apetit scăzut, suspicionându-se o hemopa-

TABELUL 1. Examenul clinic al cazurilor raportate

\begin{tabular}{|c|c|c|c|c|c|}
\hline & Cazul 1 & Cazul 2 & Cazul 3 & Cazul 4 & Cazul 5 \\
\hline Vârsta & 15 ani & 4 luni & 6 luni & 11 ani & 8 luni \\
\hline Sex & $\mathrm{F}$ & $M$ & $\mathrm{~F}$ & $\mathrm{~F}$ & $\mathrm{~F}$ \\
\hline Starea generală & $\begin{array}{l}\text { fa gabilitate, ape t } \\
\text { capricios }\end{array}$ & Ape t capricios & $\begin{array}{l}\text { Ape t capricios, IP }<0,6 \\
\text { (distrofie grad III) }\end{array}$ & bună & $\begin{array}{l}\text { Ape t capricios, } I P=0,76 \\
\text { (distrofie grad II) }\end{array}$ \\
\hline $\begin{array}{l}\text { Culoarea } \\
\text { tegumentelor }\end{array}$ & $\begin{array}{l}\text { Paloare cu tentă } \\
\text { teroasă }\end{array}$ & $\begin{array}{l}\text { Paloare, icter } \\
\text { moderat }\end{array}$ & $\begin{array}{l}\text { Paloare marcată, edem facial, } \\
\text { turgor diminuat }\end{array}$ & paloare & paloare \\
\hline $\begin{array}{l}\text { Anomalii ale } \\
\text { mucoaselor }\end{array}$ & $\begin{array}{l}\text { paloare, limbă roșie, } \\
\text { netedă, depapilată, } \\
\text { hipertrofie gingivală } \\
\text { ușoară }\end{array}$ & paloare & paloare, edem conjunc val & $\begin{array}{l}\text { Candidoză, } \\
\text { ragade } \\
\text { comisurale }\end{array}$ & paloare \\
\hline Tonus muscular & normal & hipotonie & $\begin{array}{l}\text { Slăbiciune musculară } \\
\text { generalizată }\end{array}$ & normal & Ușoară hipotonie \\
\hline $\begin{array}{l}\text { Anomalii } \\
\text { osteoar culare }\end{array}$ & normal & normal & $\begin{array}{l}\text { Torace rahi c, } \\
\mathrm{FA}=2 / 1 \mathrm{~cm} \text {, deprimată }\end{array}$ & normal & normal \\
\hline $\begin{array}{l}\text { Prezenţa } \\
\text { splenomegaliei }\end{array}$ & $\mathrm{Nu}$ & $\mathrm{Da}$ & $\mathrm{Nu}$ & $\mathrm{Nu}$ & $\mathrm{Nu}$ \\
\hline $\begin{array}{l}\text { Aspectul } \\
\text { scaunului }\end{array}$ & normal & normal & Diaree cronică & normal & Scaune cu mucus \\
\hline
\end{tabular}

TABELUL 2. Analizele de laborator ale cazurilor raportate

\begin{tabular}{|c|c|c|c|c|c|}
\hline & Cazul 1 & Cazul 2 & Cazul 3 & Cazul 4 & Cazul 5 \\
\hline $\mathrm{Hgb}(\mathrm{g} / \mathrm{dl})$ & 5,6 & 4,9 & 6,8 & 11,4 & 6,9 \\
\hline $\mathrm{MCV}(\mathrm{fL})$ & 97,7 & 73,7 & 97,5 & 107,0 & 98,1 \\
\hline $\mathrm{MCHC}(\mathrm{g} / \mathrm{dl})$ & 35,0 & 37,6 & 37,2 & 33,8 & 31,4 \\
\hline Leucocite $\left(/ \mathrm{mm}^{3}\right)$ & 4.900 & 7.000 & 3.900 & 6.200 & 5.260 \\
\hline Trombocite $\left(/ \mathrm{mm}^{3}\right)$ & 132.000 & 56.000 & 88.000 & 68.000 & 131.000 \\
\hline Re culocite (\%o) & 12 & 8 & 6 & 30 & 10 \\
\hline Vitamina B12 (pg/ml) & 33 & $<50$ & - & 56 & 91 \\
\hline Homocisteina $(\mu \mathrm{mol} / \mathrm{I})$ & 51,91 & - & - & - & - \\
\hline Acid folic (ng/ml) & - & 16,4 & - & - & 30,02 \\
\hline Sideremia $(\mu \mathrm{mol} / \mathrm{I})$ & 19,90 & 29,69 & 13,06 & 19,92 & 15,85 \\
\hline \multicolumn{6}{|c|}{$\begin{array}{l}\mathrm{Hgb}=\text { Hemoglobina, } \mathrm{MCV}=\text { volum mediu corpuscular, } \mathrm{MCHC}=\text { concentraţia medie a hemoglobinei corpusculare } \\
\text { Vitamina B12 valori normale } 191-663 \mathrm{pg} / \mathrm{ml} \text {, Homocisteina valori normale }<10 \mu \mathrm{mol} / \mathrm{l} \text {, } \\
\text { Acid folic valori normale } 4,6-18,7 \mathrm{ng} / \mathrm{ml}\end{array}$} \\
\hline
\end{tabular}


tie malignă. Examenul clinic este prezentat în tabelul 1, iar rezultatele analizelor de laborator au confirmat un deficit sever de vitamina $B_{12}$, după cum se observă în tabelul 2. Frotiul periferic şi examenul de măduva osoasă sunt descrise în tabelul 3, iar caracteristicile examenului medular sunt prezentate în figura 1. S-a iniţiat transfuzie de masă eritrocitară, ulterior tratament substitutiv cu vitamina $B_{12}$ intramuscular, evoluția fiind favorabilă. Cazul a fost interpretat ca o anemie megaloblastică prin greşeli de nutriție.

\section{Cazul 2}

Sugar, de sex masculin, în vârstă de 4 luni, s-a internat pentru paloare muco-tegumentară accentuată. Din antecedentele heredocolaterale reținem că mama a fost diagnosticată cu anemie gravidică prin carență mixtă de fier, vitamina $B_{12}$ şi acid folic, având un regim alimentar strict vegetarian. Antecedentele personale fiziologice evidențiază o naştere la termen, pe cale naturală, greutatea la naştere $3.000 \mathrm{~g}$, Apgar 9/1min, alăptat exclusiv până în prezent, vaccinat, diagnosticat la 4 luni cu sindrom hipoton.

Examenul clinic este descris în tabelul 1, iar analizele de laborator sunt prezentate în Tabelul 2 şi Tabelul 3, confirmând anemia severă datorată deficienței vitaminei B12. Aspectul măduvei osoase este prezentat în figura 2 . S-a efectuat electroforeza hemoglobinei: Hgb A 89,8\% Hgb A2 4,6\%, Hgb F $5,6 \%$. S-a iniţiat transfuzie cu masă eritrocitară şi transfuzie de trombocite, vitamina $\mathrm{B}_{12}$ intramuscular. Cazul a fost interpretat ca o anemie megaloblastică şi betatalasemie minoră.

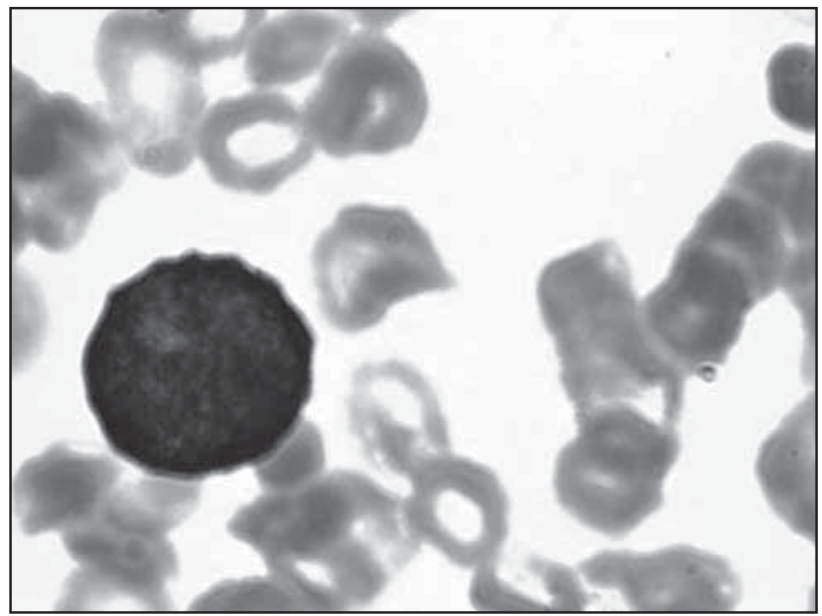

FIGURA 2. Aspirat de măduvă osoasă - seria eritroblastică cu hiperplazie moderată şi megaloblaşti

\section{Cazul 3}

Sugar, de sex feminin, în vârstă de 6 luni, s-a internat pentru apetit capricios, curbă ponderală
TABELUL 3. Caracteristicile frotiului periferic şi ale aspiratului medular

\begin{tabular}{|c|c|c|c|c|c|}
\hline Frotiu periferic & Cazul 1 & Cazul 2 & Cazul 3 & Cazul 4 & Cazul 5 \\
\hline Macro-ovalocite & + & + & + & + & + \\
\hline Anizocitoză & + & + & + & - & + \\
\hline Poikilocitoză & - & + & + & - & - \\
\hline $\begin{array}{l}\text { Eritrocite cu inele } \\
\text { Cabot }\end{array}$ & + & + & - & - & - \\
\hline $\begin{array}{l}\text { Corpi Howell- } \\
\text { Jolly }\end{array}$ & + & + & - & - & + \\
\hline Macrotrombocite & + & + & - & + & - \\
\hline $\begin{array}{l}\text { Neutrofile } \\
\text { hipersegmentate }\end{array}$ & + & - & - & + & - \\
\hline \multicolumn{6}{|l|}{ Aspirat medular } \\
\hline \begin{tabular}{|l|} 
Hiperplazie \\
eritroidă
\end{tabular} & + & + & - & + & + \\
\hline $\begin{array}{l}\text { Metamielocite } \\
\text { gigante }\end{array}$ & + & + & + & + & + \\
\hline Megaloblastoză & + & + & + & + & + \\
\hline $\begin{array}{l}\text { Corpi Howell- } \\
\text { Jolly }\end{array}$ & + & + & - & + & + \\
\hline \begin{tabular}{|l|} 
Neutrofile \\
hipersegmentate
\end{tabular} & + & - & + & + & - \\
\hline
\end{tabular}

descendentă, scaune semiconsistente, paloare marcată muco-tegumentară. Din antecedentele personale fiziologice reținem: naştere la termen, pe cale naturală, greutatea la naştere $3.200 \mathrm{~g}$, Apgar 10/1min, alăptat exclusiv aproximativ o lună, ulterior cu lapte de capră, vaccinat, nediversificat, internat în Clinica Pediatrie I la vârsta de 2 luni cu bronşiolită.

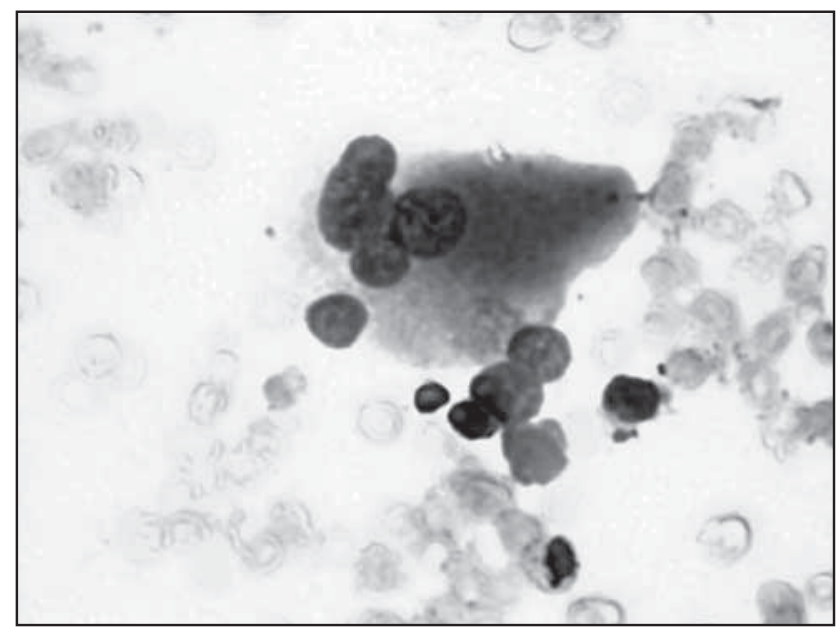

FIGURA 3. Aspirat de măduvă osoasă - megacariocite cu nucleu în explozie

Examenul clinic este descris în tabelul 1, iar modificările de laborator sunt prezentate în tabelul 2. Frotiul periferic şi examenul măduvei osoase sunt descrise în tabelul 3, confirmând anemia megaloblastică. Aspectul măduvei osoase este prezentat 
în Figura 3. S-a administrat acid folic pe cale orală şi vitamina $B_{12}$ intramuscular, deşi dozarea folatului şi a vitaminei $B_{12}$ nu a fost efectuată din motive obiective, din cauza complianței scăzute şi a faptului că mama s-a externat la cerere. Mama a fost, de asemenea, consiliată cu privire la modificarea dietei. În acest caz, anemia megaloblastică a fost interpretată în contextul malnutriției protein-calorice, a multiplelor greşeli alimentare şi a condițiilor socioeconomice sărace.

\section{Cazul 4}

Pacientă în vârstă de 11 ani, diagnosticată de la vârsta de 6 săptămâni cu candidoză muco-cutanată, ulterior la vârsta de 10 ani cu poliendocrinopatie autoimună tip I, fiind dispensarizată endocrinologic, pe parcursul multiplelor evaluări, pacienta prezintă trombocitopenie, motiv pentru care s-a internat pentru evaluare hematologică. Antecedentele personale patologice sunt: candidoză muco-cutantă, hipoparatiroidism, insuficiență corticosuprarenală primară.

Anomaliile examenului clinic sunt prezentate în tabelul 2, iar investigațiile de laborator sunt prezentate în tabelul 2 şi tabelul 3, confirmând anemia megaloblastică. Aspectul frotiului periferic este prezentat în Figura 4. Tratamentul de substituție a fost inițiat $\mathrm{cu}$ vitamina $\mathrm{B}_{12}$ intramuscular. În acest caz, anemia megaloblastică a fost interpretată ca parte a poliendocrinopatiei autoimune.

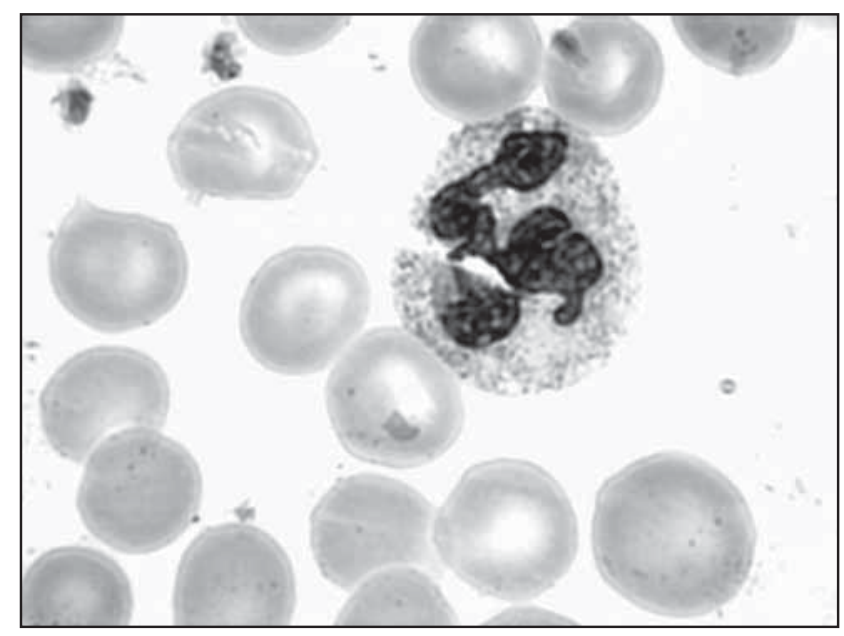

FIGURA 4. Frotiu sanguin periferic - se observă macrocitoză şi neutrofile hipersegmentate

\section{Cazul 5}

Sugar în vârstă de 8 luni, de sex feminin, provenit din mamă cunoscută cu anemie megaloblastică, s-a internat pentru apetit capricios şi curbă ponderală lent ascendentă, fiind aparent fără antecedente personale patologice. Anomaliile examenului cli- nic sunt prezentate în tabelul 1, iar investigațiile de laborator sunt prezentate în tabelul 2 şi tabelul 3, confirmând anemia megaloblastică. Aspectul frotiului periferic este prezentat în Figura 5. S-a iniţiat tratament de substituție cu masă eritrocitară, ulterior vitamina $\mathrm{B}_{12}$ intramuscular. Acest caz a fost interpretat ca anemie megaloblastică la un sugar a cărui mamă a fost diagnosticată cu anemie megaloblastică ce a răspuns prompt la substituția cu vitamina $\mathrm{B}_{12}$.

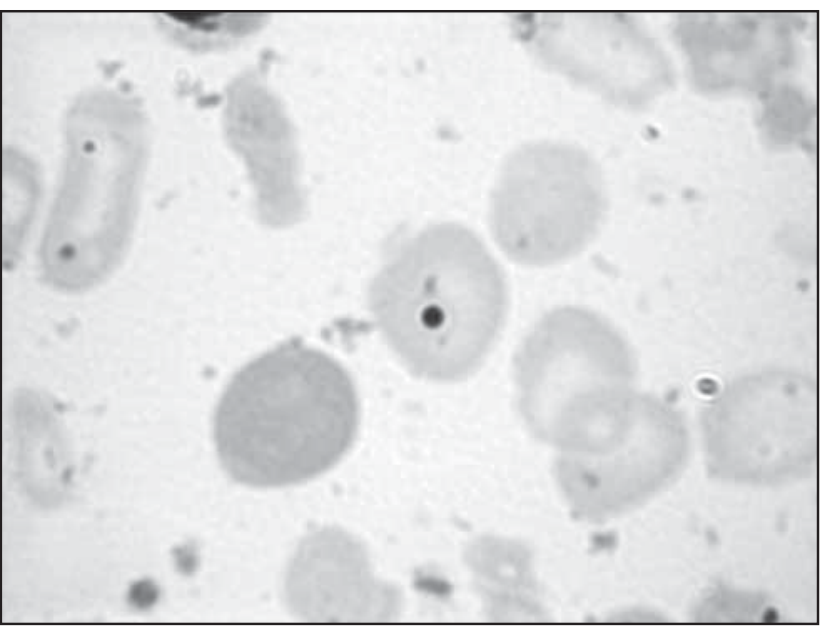

FIGURA 5. Frotiu sanguin periferic - se observă eritrocite cu corpi Howell-Jolly

\section{DISCUŢII}

Frecvența anemiei megaloblastice variază în funcție de regiunile geografice, fiind mult mai mare în Olanda, țările scandinave, SUA, Canada versus sudul şi estul Europei, însă nu se exclude faptul că această anemie este răspândită în comparație cu datele înregistrate şi că probabil nu este diagnosticată în toate cazurile (6). Anemia megaloblastică prin deficit de folați este frecvent atestată în țările slab dezvoltate economic, cu un nivel scăzut de trai şi cu o alimentație insuficientă (7).

Sugarii cu anemie megaloblastică pot avea paloare, icter moderat, pot fi mai iritabili, cu apetit capricios, în timp ce copiii mai mari pot avea senzație de amorțeală şi slăbiciune; aceste simptome au fost descrise în cele cinci cazuri prezentate, fiind similare cu multe studii raportate (8-10).

Anemia megaloblastică este o cauză importantă de citopenie. Inițial, se efectuează o hemoleucogramă şi un frotiu periferic (11), observându-se: o valoare scăzută a hemoglobinei şi a eritrocitelor, MCV crescut (> $100 \mathrm{fL}$ ), concentrația medie a hemoglobinei corusculare (MCHC) în limite normale, trombocitopenie, scăderea numărului de reticulocite, frotiul periferic cu ovalocite, anizocitoză, 
poikilocitoză, hematii cu inele Cabot, corpi Howell-Jolly, trombocite mari, neutrofile hipersegmentate $(1,2,4)$. Uneori, sunt detectate semne de hemoliză cu valori crescute ale dehidrogenazei acidului lactic şi ale bilirubinei indirecte, care pot fi atribuite distrugerii intramedulare a eritrocitelor (12). Examenul măduvei osoase evidenţiază hiperplazie eritroidă, metamielocite gigante, megaloblastoză, corpi Howell-Jolly, neutrofile hipersegmentate (6). Nivelurile serice scăzute ale vitaminei B12 şi ale acidului folic susțin diagnosticul.

Cele cinci cazuri prezentate ilustrează debutul bolii la vârste diferite şi în patologii diferite. Astfel, primii doi pacienți prezintă debutul bolii la 14 ani şi, respectiv, 4 luni, cu paloare tegumentară şi fatigabilitate. Analizele de laborator relevă în ambele cazuri anemie severă şi trombocitopenie, frotiul cu macrocitoză, aspiratul medular pledând pentru o anemie megaloblastică, confirmată prin dozarea vitaminei B12.

Ravikumar et al. au raportat că, într-un grup de 40 de adolescenți cu anemie megaloblastică, 82,5\% au avut un regim vegetarian sau predominant vegetarian (9). Suarez T et al. au raportat deficiențe de fier, acid folic şi vitamina B12 la 34,6\%, respectiv 90,9\% şi, respectiv, 18,1\% la adolescenții anemici în vârstă de 12-19 ani (13). Suplimentarea alimentelor cu acid folic, vitamina B12 şi alți micronutrienți este o măsură cu un cost redus şi ar putea fi eficientă pentru controlul anemiei la populațiile cu risc crescut. Sugarul în vârstă de 4 luni a fost hrănit doar în mod natural, cauza deficitului de vitamina B12 fiind dieta strict vegetariană a mamei în timpul sarcinii şi mai târziu, însoțită de lipsa suplimentării vitaminice. Anemia megaloblastică datorată deficienței vitaminei B12 la sugarii exclusiv alăptați, născuți de mamele vegetariene, a fost raportată de alți autori şi este o cauză importantă a retardului neuromotor (14-18).

Sugarul de 4 luni a fost alimentat exclusiv natural, cauza deficitului de vitamina B12 fiind dieta strict vegetariană a mamei pe parcursul sarcinii şi ulterior însoțită de lipsa suplimentării vitaminice. Deficiența de vitamina B12 apare frecvent la sugarii născuți din mame vegetariene şi este o cauză importantă de anemie şi retard neuromotor. Pe baza electroforezei hemoglobinei, la acest pacient s-a evidențiat şi o betatalasemie minoră asociată, care a mascat macrocitoza şi a explicat astfel valoarea mai mică a MCV-ul $(73,7 \mathrm{fL})$. Al cincilea pacient se încadrează, de asemenea, în categoria anemiei megaloblastice produse de carența suplimentării vitaminice, însă în contextul unei anemii megaloblastice materne.
Următorii doi pacienți au fost diagnosticați în mod întâmplător cu anemie megaloblastică, în contextul patologiei asociate. Astfel, al treilea pacient este diagnosticat cu sindrom de malabsorbție, distrofie gr. III, greşeli alimentare, context în care aspectul frotiului periferic ridică suspiciunea de anemie megaloblastică, confirmată prin aspirat medular. Într-un studiu din India, efectuat pe un lot de 29 sugari cu anemie megaloblastică, malnutriția protein-calorică a fost documentată în 14 cazuri, toți pacienții au avut valoarea $\mathrm{Hgb}$ sub $10 \mathrm{~g} / \mathrm{dl}$, dintre care mai mult de jumătate au avut anemie severă. Dozarea vitaminei B12 şi a acidului folic s-a făcut în doar 10 cazuri, evidențind fie un deficit combinat de vitamina B12 şi folați, fie o carență izolată de vitamina B12 sau acid folic. La restul pacienților, diagnosticul de anemie megaloblastică s-a precizat pe baza aspectului frotiului periferic şi medular (19).

Cazul 4 reprezintă o pacientă în vârstă de 11 ani diagnosticată cu poliendocrinopatie autoimună tip I, context în care apare trombocitopenia neexplicată, ce ne conduce spre efectuarea investigatiilor hematologice, respectiv a examenului medular şi, în cele din urmă, dozarea vitaminei B12, care confirmă diagnosticul. Literatura de specialitate aminteşte de bolile autoimune ca fiind un factor declanşator al anemiei megaloblastice. Astfel, au fost raportate cazuri asociate de anemie megaloblastică cu anemie hemolitică autoimună, cu artrită reumatoidă sau cu tiroidită autoimună, sindrom Sjögren şi lupus eritematos (20-22).

Anemia megaloblastică este, în general, suspectată la copiii cu anemie cu MCV crescut şi ar trebui să fie suspectată la toți copiii care au bicitopenie sau pancitopenie (23). Această serie de cazuri a descris variatele prezentări ale anemiei megaloblastice la copii şi în patologii diferite.

\section{CONCLUZII}

Anemia megaloblastică este o anemie rar diagnosticată la copil, probabil subdiagnosticată, având cauze multiple, apărând în contextul unui deficit congenital de vitamina $\mathrm{B}_{12}$, asociat unei boli autoimune, dar şi în condițiile socio-economice precare, în caz de malnutriție protein-calorică, alimentație strict vegetariană a mamei în timpul sarcinii (asociată cu lipsa substituției în timpul sarcinii şi pe parcursul alăptării) şi, nu în ultimul rând, asociat cu anemia megaloblastică maternă. Suplimentarea cu vitamina $\mathrm{B}_{12}$ ar trebui oferită tuturor mamelor pe perioada sarcinii şi postnatal pe perioada alăptării, alături de fier şi acid folic, în special în cazul celor vegetariene şi a celor care provin din mediu socio-economic precar. 